Int. J. Dev. Biol. 52: 151-155 (2008)

doi: $10.1387 / \mathrm{ijdb} .072325 \mathrm{zs}$

\title{
Animal reproduction biotechnology in Poland
}

\author{
ZDZISLAW SMORAG*, LUCYNA KATSKA-KSIAZKIEWICZ, MARIA SKRZYSZOWSKA, JACEK JURA, \\ BARBARA GAJDA and MICHAL BOCHENEK \\ National Research Institute of Animal Production, Department of Biotechnology of Animal Reproduction, Balice, Poland
}

\begin{abstract}
The key research areas of the Department are: in vitro production of embryos, embryo cryopreservation, animal transgenesis, cloning, cytometric semen sexing and evaluation. Research has been focused on the in vitro production of animal embryos, including the development of complex methods for oocyte maturation, fertilization and embryo culture. Moreover, experiments on long-term culturing of late preantral and early antral bovine ovarian follicles have been developed. Studies on the cloning of genetically modified pigs with "humanized" immunological systems have been undertaken. A cloned goat was produced from oocytes reconstructed with adult dermal fibroblast cells. The novel technique of rabbit chimeric cloning for the production of transgenic animals was applied; additionally, the recipient-donor-cell relationship in the preimplantation developmental competences of feline nuclear transfer embryos has been studied. Regarding transgenic animal projects, gene constructs containing growth hormone genes connected to the $\mathrm{mMt}$ promoter were used. Modifications of milk composition gene constructs with tissue-specific promoters were performed. Moreover, pigs for xenotransplantation and animal models of human vascular diseases have been produced. Over the last 15 years, our flow cytometry research group has focused its work on new methods for sperm quality assessment and sex regulation. In the 1970s, our team initiated studies on embryo cryopreservation. As a result of vitrification experiments, the world's first rabbits and sheep produced via the transfer of vitrified embryos were born.
\end{abstract}

KEY WORDS: animal cloning, transgenesis, sex regulation, cryopreservation

The Department of Biotechnology of Animal Reproduction in the National Research Institute of Animal Production was founded in 1950 as one of the institutes of the Ministry of Agriculture. During the first years of its history, the Department focused on practical issues related to insemination of cattle and horses. Prof. Wladyslaw Bielanski (Fig.1), the first Head of the Department, emphasized the practical side of research. In the mid 1960s, the Central Bank of Bull Semen was created for breeding evaluation, microbiological control of stored semen, and import and export of frozen semen.

Prof. Stefan Wierzbowski, who became the Head of the Department in 1968, continued this practical approach and focused on the improvement of artificial insemination methods for various animal species, the development of semen preservation and evaluation methods, and animal behaviour and andrology.

During the second half of the 1970s, the scope of the research in the Department was broadened to include aspects of female reproductive biology. Research on superovulation, embryo transfer and cryopreservation for several species of mammals was then initiated. In the 1980s, these studies were widened to encompass the in vitro production of embryos and embryo cloning. At the beginning of the 1990s, research on animal transgenesis and sex regulation was initiated. At present, the key research areas are: in vitroproduction of embryos, embryo cryoconservation, animal transgenesis, cloning, and cytometric semen sexing and evaluation. Prof. Zdzislaw Smorag has been the Head of the Department since 1992.

The Department collaborates with several Polish and foreign research groups representing various research disciplines; this collaboration has led to several interdisciplinary projects in animal reproduction, pharmacy and medicine.

\section{In vitro production of embryos}

Research focused on the in vitroproduction of animal embryos includes the development of complex methods for oocyte maturation, fertilization and embryo culture. This research was initiated on cattle and goats in the last century. At the end of the last

\footnotetext{
*Address correspondence to: Zdzislaw Smorag. National Research Institute of Animal Production, ul. Krakowska 1, 32-083 Balice. e-mail: zsmorag@izoo.krakow.pl Web: www.izoo.krakow.pl
}

Published online: 14 February 2008

0214-6282/2008/\$35.00

(C) UBC Press

Printed in Spain 


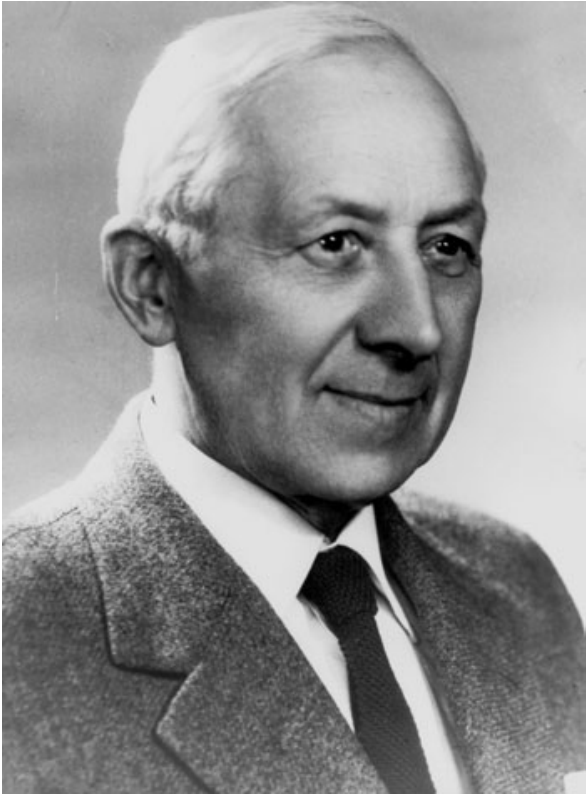

Fig. 1. Professor Wladyslaw Bielanski (1911-1982) was the first Head of the Dept. of Biotechnology of Animal Reproduction (National Research Institute of Animal Production, Polish Ministry of Agriculture).

century, experiments on long-term culturing of late preantral and early antral bovine ovarian follicles were initiated with the ultimate goal of more effectively utilizing female reproductive potential.

In 1990, the first calf from a transferred blastocyst produced through complex in vitro technology was born in Balice (Fig. 2) (Katska et al., 1991). Our studies showed that the method of oocyte collection has a profound effect on the number of recovered oocytes. We found that when the oocytes were recovered by rupturing isolated follicles, more normal oocytes per animal were recovered then when the aspiration method was used. However there was no correlation between the number of ovarian follicles and the quality of the recovered oocytes. We also found that most of the oocytes were able to mature at temperatures ranging from $35^{\circ} \mathrm{C}$ to $39^{\circ} \mathrm{C}$ (Katska and Smorag, 1985). We have shown that, for the cattle, hardening of the zona pellucida occurred both in vivo and in vitro. Hardening can be induced after keeping immature or mature, cumulus-free oocytes in homological as well as heterological (rabbit or sheep) oviducts, in vitro or in vivo. Zona hardening tremendously affects oocyte fertilizability and embryo development (Katska et al., 1989). Our studies of sperm capacitation for IVF purposes have provided evidence that bull variability, the source of sperm (ejaculated or cauda-epididymal, fresh or frozen-thawed) and, the presence of seminal plasma play crucial roles in in vitro embryo production in cattle (Katska at al., 1996).

Studies of late preantral and early antral ovarian follicles focused on the relationships between different culturing systems and in vitrosurvival, as well as the meiotic competence of bovine oocytes recovered from early antral ovarian follicles (KatskaKsiazkiewicz and Alm, 2005).

Experiments on the in vitro production of goat embryos have led to the development of methods for recovery of oocytes from slaughtered animals; successful capacitation, for both fresh and frozen-thawed caprine sperm; and embryo culturing to the blastocyst stage in co-culture with goat oviduct epithelial cells (Katska-
Ksiazkiewicz et al., 2004).

Our studies on oocyte recovery and maturation in the domestic cat led to the development of a culture system in which cat GV oocytes matured and reached metaphase II (Katska-Ksiazkiewicz et al., 2003).

\section{Experimental production of twins}

Studies of methods for twin production were initiated in the 1980s. This research focused on embryo bisection in mice, sheep and cattle. Embryo bisection is a traumatic procedure that destroys a certain number of cells and can reduce the implantation capacity of transferred demi-embryos. Our experiments showed that, in late blastocysts of sheep and cattle, $12 \%-13 \%$ of the cells were lost during bisection (Skrzyszowska and Smorag, 1989). Therefore, to diminish cell loss, a non-invasive method of bisecting bovine embryos was developed. It consisted of perforating (cutting) the zona pellucida in the vicinity of the inner cell mass (ICM) of blastocysts and leaving the embryos for further growth until hatching. During hatching, approximately $50 \%$ of the blastocysts protruded through the hole in the zona in such a way that at a certain moment they acquired the shape of figure "8" with the ICM split into halves, with one half located outside the zona and one still inside it. The splitting of figure-eight-shaped, hatching blastocysts involves minimal cell losses, which are limited to the narrow cell bridge connecting the two parts of the hatching embryo. The transfer of demi-embryos produced by this method resulted in many pairs of monozygotic twins (Skrzyszowska et al., 1999).

\section{Animal cloning}

In the late 1990s, we initiated studies on somatic-cell cloning of different species of farm animals (pigs, goats, and rabbits) and companion animals (domestic cats).

\section{Pig}

We have undertaken studies on somatic-cell cloning of genetically modified pigs with "humanized" immunological systems. We transferred the nuclei of dermal fibroblast cells derived from heterozygous and homozygous transgenic boars expressing

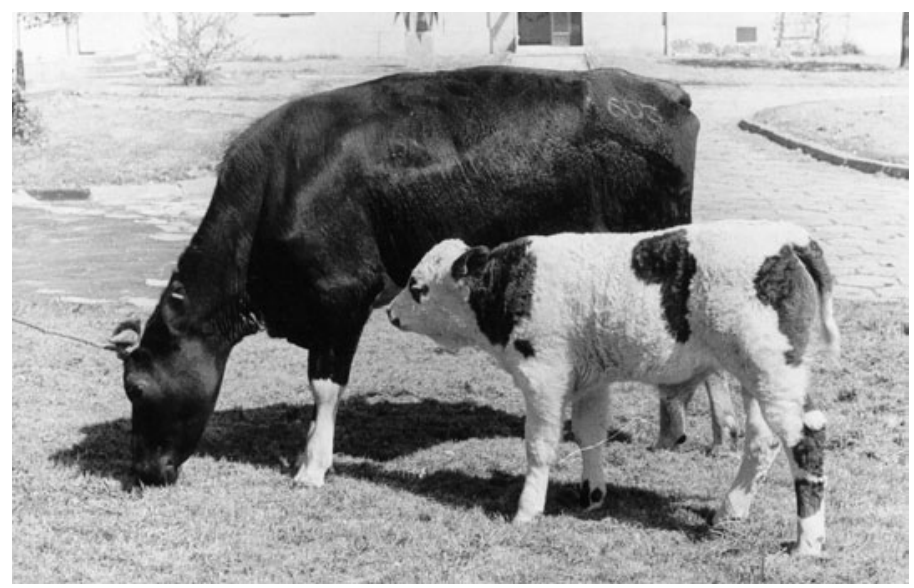

Fig. 2. First calf born in Poland following the transfer of an in vitro produced (IVP) embryo - 1990. 

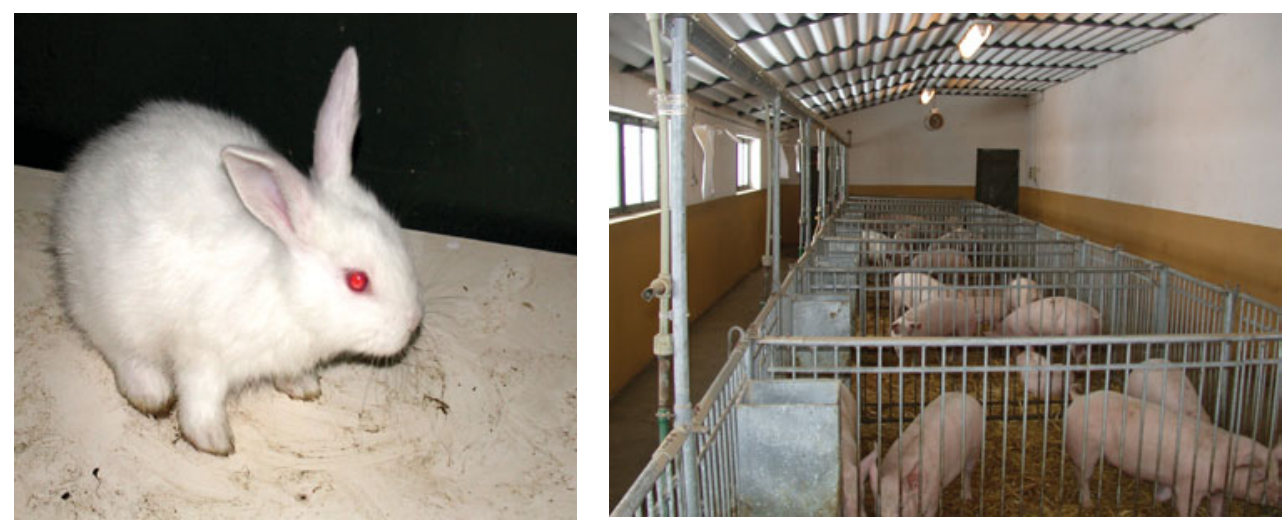

Fig. 3 (Left). The $\mathbf{T g}(\mathbf{W a p}-\mathbf{G H 1}$ ) transgenic rabbit NT20 generated from a partially reconstructed 2cell embryo - obtained in 2006.

Fig. 4 (Right). Transgenic pig line established in 2006, Zerniki, Poland.

recombinant human $\mathrm{H}$-transferaes $(\alpha-1,2$-fucosylosyltransferase; $\alpha-1,2$-rhFT) into enucleated porcine oocytes. Approximately $30 \%$ of the resulting pig embryos developed in vitro up to the morula and blastocyst stages. After transfer of the embryos into synchronized recipient gilts or sows, pregnancies were confirmed in 10 females out of 39 recipients. However, resorption of fetuses occurred between days 35 and 47 of pregnancy (unpublished).

In other experiments, in-vitro-cultured, fetal or adult dermal fibroblast cells (confluent or serum-starved) were subjected to cytometric analysis of the mitotic cell cycle together with the detection of late-apoptotic cells. The cytometric analysis confirmed the high efficiency of the artificial synchronization of the mitotic cycle at G0/G1 stages induced by contact inhibition or serum deprivation and allowed us to distinguish between apoptotic and non-apoptotic fibroblasts. We determined that the method used for synchronization of nuclear donor cells and the type of fibroblast cells used for the reconstruction of enucleated oocytes influenced the in vitro developmental capabilities of porcine nuclear-transferred embryos. We also observed that the in vitro developmental potential (to the morula/blastocyst stages) of porcine cloned embryos derived from the oocytes reconstructed with non-apoptotic fetal fibroblast cells was higher than that for embryos derived from oocytes reconstructed with non-apoptotic adult dermal fibroblast cells (Skrzyszowska and Samiec, 2005).

\section{Goat}

We have evaluated the in vivo developmental potential of caprine cloned embryos derived from oocytes reconstructed with cell nuclei of cumulus and fetal or adult ear skin-derived fibroblast cells. So far, we have been able to generate two cloned goats, which developed from oocytes reconstructed with adult dermal fibroblast cells (unpublished).

\section{Rabbit}

We applied a novel technique of chimeric somatic-cell cloning for the production of transgenic rabbits. Transgenic adult skinderived fibroblast cells containing the $\mathrm{Tg}(\mathrm{Wap}-\mathrm{GH} 1)$ gene were microsurgically transferred into one, previously enucleated, blastomere of a two-cell non-transgenic embryo, while leaving the second cell intact. The reconstructed embryos were either cultured in vitroup to the blastocyst stage or transferred into recipient females immediately after the cloning procedure. PCR analysis showed that the transgene was detected in the cells of four out of 14 blastocysts. Out of nine recipient females, four (44.4\%) became pregnant and delivered a total of 24 $(14.7 \%)$ pups. The PCR analysis revealed that two pups $(1.2 \%)$, one alive and one stillborn, showed a positive transgene signal. The live transgenic rabbit NT20 (Fig. 3) appeared healthy and anatomically and physiologically normal. These results showed that a transgenic, adult, dermal fibroblast cell nucleus which has been introduced into the cytoplasmic microenvironment of a single, enucleated blastomere from a two-cell-stage rabbit embryo can direct the development of a chimeric embryo not only to the blastocyst stage but also to term (Skrzyszowska et al., 2006).

\section{Domestic cat}

We studied the effects of the recipient cytoplast's age and the type of somatic cells used as donor nuclei on the preimplantation developmental competences of feline NT embryos. We showed that cloned embryos derived from reconstructed oocytes which had been matured in vitro for less than $35 \mathrm{~h}$ had increased developmental capability and are able to reach the blastocyst stage. To our knowledge, this was the first report of the successful generation of feline nuclear-transferred blastocysts (Skrzyszowska et al., 2001; Skrzyszowska et al., 2002).

\section{Animal transgenesis}

In 1989, our team initiated studies of transgenesis in farm animals: rabbits, goats, pigs, and cattle. The basic method which we use is the microinjection of DNA into the pronucleus of a fertilized egg produced in vivo or in vitro (Jura et al., 1994).

During the initial period of producing transgenic farm animals, we mostly used gene constructs containing growth hormone genes under the control of the mMt (mouse Metallothionein) promoter. Afterwards we also used gene constructs with tissuespecific promoters, which have been used to modify the composition of milk, to obtain proteins of therapeutic value in milk, and to create animal models of human vascular diseases. For these studies, we collaborated with the leading research groups from Harvard Medical School, Boston, USA; Institute National de la Recherche Agronomique, France; and Edison Biotechnology Institute, Ohio University, USA.

At the end of the 1990s, we started a collaboration with the Department of Biochemistry and Biotechnology of the Academy of Agriculture in Poznan. This collaboration resulted in the establishment of a line of transgenic rabbits which secrete human growth hormone in their milk (Lipinski et al., 2003a). We also participate in a multidisciplinary project (realized by 11 medical and biotechnological research groups from Poland) focused on xenotransplantation. These studies have led to the production of a line of genetically modified pigs (including homozygous individuals) (Fig. 4). Clinical studies showed that after perfusion of an 


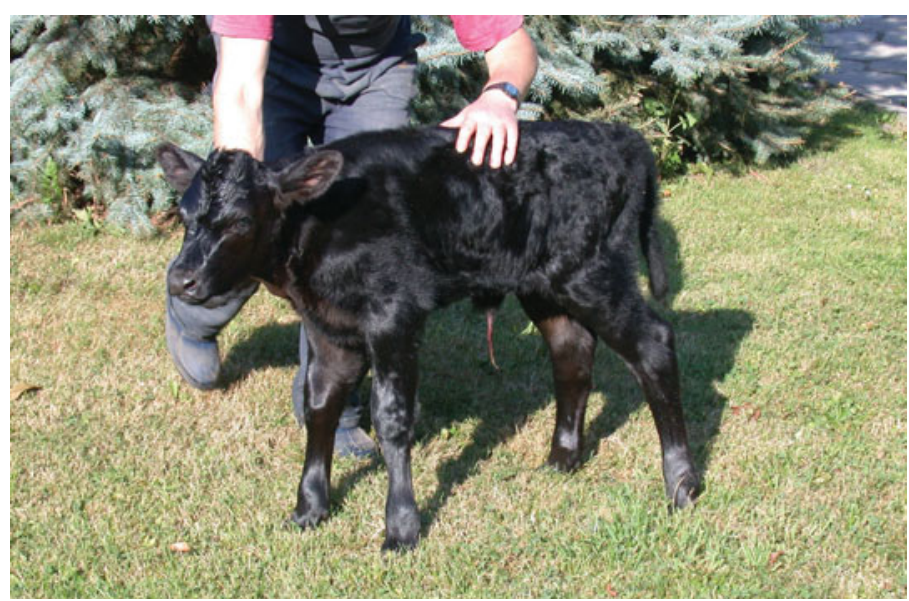

Fig. 5. First calf in Poland born in 2005 after standard insemination with sexed semen ( $X$ fraction).

isolated transgenic pig heart with human blood, acute phase rejection was delayed (Skarysz and Bochenek, 2006).

At present, a new generation of constructs containing various reporter genes is being utilized in transgenic pig research. The goal of this project is to obtain human interferon alpha and human blood serum in the milk of transgenic pigs (Lipinski et al., 2003b).

\section{Flow cytometry studies}

Over the past 15 years, our flow cytometry research group has focused its work on studies of animal spermatozoa and new methods for sperm quality assessments. These studies led, in 2003, to a spectacular result: the first calf in Poland produced via insemination with sexed semen (Fig. 5; Bochenek and Smorag, 2005). Now, over 100 calves have been born in Poland after standard insemination with sexed semen.

For precise examination of the status of the sperm membrane, we have used a double-fluorescent-staining procedure (Bochenek et al., 1999). The assessment of sperm chromatin structure was extensively studied as a possible novel method for analyzing sperm DNA damage. It was observed that sperm chromatin abnormalities have a large impact on male fertility (Bochenek et

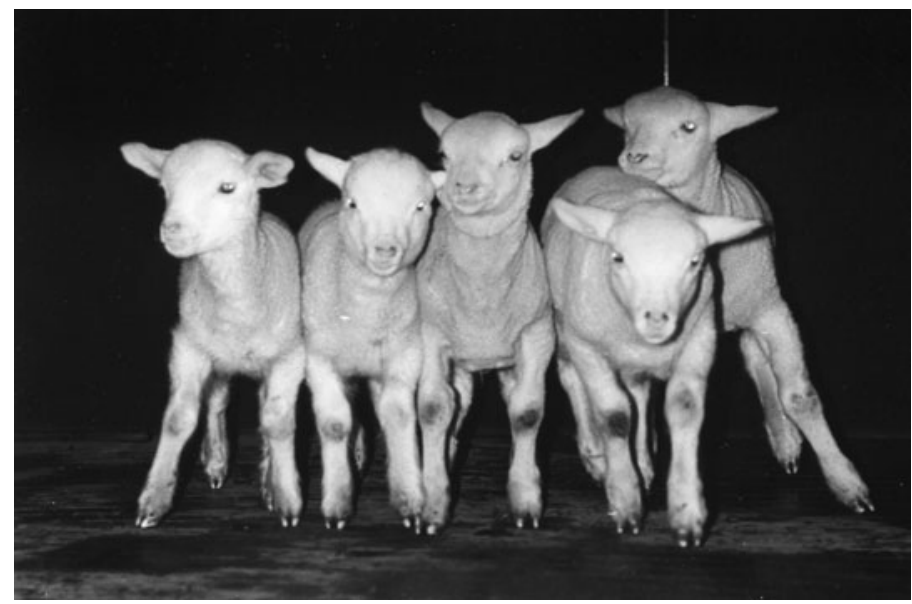

Fig. 6. The first lambs in the world to be born after the transfer of vitrified embryos - obtained in 1989. al., 2001). We observed that the sperm-sexing procedure has only very insignificant effects on the structure of sperm DNA (Bochenek et al., 2006).

\section{Oocyte and embryo cryopreservation}

In the 1970s, our team initiated studies on embryo cryopreservation. We performed experiments on the effects of freezing embryos from sheep (Smorag et al.,1978) and cattle (Smorag et al., 1981). Since the late 1980s, we have focused on vitrification. Vitrification was, at that time, a new approach for oocyte and embryo cryopreservation. Vitrification consists of solidifying a solution through a drastic increase in viscosity during cooling and not through crystallization. As a result of our work, the first rabbit (Smorag et al., 1989) and sheep (Gajda et al., 1989) (Fig. 6) in the world produced via the transfer of vitrified embryos were born. Recently, we have concentrated on vitrification of pig embryos. It was demonstrated that in-vitro-produced blastocysts are more susceptible to vitrification than blastocysts obtained in vivo. This phenomenon is specific to pig embryos: in other species, embryos obtained in vivo are more susceptible to preservation. After transfer of vitrified embryos into synchronized recipients, we obtained the first piglets in Poland born following the transfer of cryopreserved pig embryos (Gajda et al., 2004).

\section{References}

BOCHENEK M., HERJAN T., OKOLSKI A. and SMORAG Z. (2006) Sperm chromatin abnormalities after semen sexing procedure - preliminary results. Editors: H.Alm, H.Torner and JF.Wade, Havemeyer Foundation Series No. 18 13-15.

BOCHENEK M., LASZCZKA A., SLAWINSKI J., SKRZYSZOWSKA M. and SZCZESNIAK-FABIANCZYK B. (1999) Integrity of bull sperm membranes double-stained with SYBR-14 and PI, assessed by fluorescent microscopy and flow cytometry. Ann.Anim. Sci. 26: 115-125

BOCHENEK M. and SMORAG Z. (2005) Cattle sex regulation by separation of $X$ and $Y$ spermatozoa - preliminary results. Medycyna Wet. 61: 50-52.

BOCHENEK M., SMORAG Z. and PILCH J. (2001) Sperm chromatin structure assay of bulls qualified for artificial insemination. Theriogenology 56: 557-567.

GAJDA B., SMORAG Z., WIECZOREK J.(2004) Piglets obtained after transplantation of vitrified pig embryos. Medycyna Wet. 60: 371-373.

GAJDA B., SMORAG Z., WIERZBOWSKI S., JURA J. and WIECZOREK B.(1989) Transfer of vitrified sheep morula. Zuchthygiene 24: 97-100.

JURA, J., KOPCHICK, J.J., CHEN,W.Y., WAGNER, T.E., MODLINSKI, J.A., REED, M.A., KNAPP, J.R. and SMORAG, Z. (1994) In vitro and in vivo development of bovine embryos from microinjected zygotes and 2-cell embryos Theriogenology 41: 1259-1266.

KATSKAL, KAUFFOLD P, SMORAG Z, DUSCHINSKIU, TORNER H. and KANITZ W. (1989) Influence of hardening of the zona pellucida on in vitro fertilization of bovine oocytes. Theriogenology 32: 767-777.

KATSKA L, SMORAG Z, BAK M, WIERZBOWSKI S. (1991) Calf developed from in vitro produced embryo. Medycyna Wet. 47: 169-171.

KATSKA L, RYNSKA B. and SMORAG Z. (1996) Effect of seminal plasma on the in vitro fertilizability of bull spermatozoa. Anim. Reprod. Sci. 44: 23-31.

KATSKA L. and SMORAG Z. (1985) The influence of culture temperature on in vitro maturation of bovine oocytes. Anim. Reprod. Sci. 9: 205-212.

KATSKA-KSIAZKIEWICZ L. and ALM H. (2005) Effect of culture methods on cumulus and oocyte morphology and meiotic competence of bovine oocytes from early antral follicles. Arch. Tierz. Dummerstorf 48: 562-571.

KATSKA-KSIAZKIEWICZ L, RYNSKA B, GAJDA B. and SMORAG Z. (2004) Effect of donor stimulation, frozen semen and heparin treatment on the efficiency of in vitro embryo production in goats. Theriogenology 62: 576-586. 
KATSKA-KSIAZKIEWICZ L, RYNSKA B, KANIA G, SMORAG Z, GAJDA B, and PIENKOWSKI M. (2003) Timing of nuclear maturation of non-stored and stored domestic cat oocytes. Theriogenology 59: 1567-1574.

LIPINSKI, D., JURA, J., KALAK, R., PLAWSKI, A., KALA, M., SZALATA, M., JARMUZ, M., KORCZ, A., SLOMSKA, K., JURA, J., GRONEK,P., SMORAG, Z., PIENKOWSKI, M. and SLOMSKI, R. (2003a) Transgenic rabbit producing human growth hormone in milk. J. Appl. Genet. 44: 165-174.

LIPINSKI D., SZALATA M., KALAK R., PLAWSKI A., NUC K., KALA M., JUZWA K., SLOMSKA K., GRONEK P., JURA J., JURA J., SMORAG Z., PIENKOWSKI M.and SLOMSKI R. (2003b) Ekspresyjne konstrukcje genowe prawidlowych i zmutowanych genow. Expressive gene structures of proper and modified genes. Biotechnologia 1: 48-73.

SKARYSZ J. and BOCHENEK M. (2006). Uzycie serca transgenicznych Swin w ukladzie heterologicznym z zastosowaniem krwi ludzkiej - doSwiadczenia wlasne. W: Biotechnologiczne i medyczne podstawy ksenotransplantacji. OSrodek Wydawnictw Naukowych, Poznan 2006, str. 331-340. ISBN 83-7314013-1.

SKRZYSZOWSKA M. and SAMIEC M. (2005) Production of porcine nuclear transfer embryos using fetal fibroblast cells analyzed on apoptosis. Reprod Fertil. Dev. 17: 182-183.

SKRZYSZOWSKA M. and SMORAG Z. (1989) Cell losses in bisected mouse, sheep and cattle embryos. Theriogenology 32: 115-122.

SKRZYSZOWSKA M., SMORAG Z., KATSKA L. and BOCHENEK M.(1999) Cattle twins after transfer of demi-embryos derived from zona-perforated blastocysts. J. Anim. Feed. Sci. 8: 223-231.

SKRZYSZOWSKA M., SMORAG Z., SLOMSKI R., KATSKA-KSIAZKIEWICZ L., KALAK R., MICHALAK E., WIELGUS K., LEHMANN J., LIPINSKI D., SZALATA M., PLAWSKI A., SAMIEC M., JURA J., GAJDA, B., RYNSKA B. and PIENKOWSKI M. (2006) Generation of transgenic rabbits by the novel technique of chimeric somatic cell cloning. Biol Reprod. 74: 1114-1120.

SKRZYSZOWSKA M., KATSKA L., SMORAG Z., RYNSKA B., KANIA G., GAJDA B. and PIENKOWSKI M. (2001) In vitro development of somatic nuclear transferred cat embryos. Theriogenology 55: 292.

SKRZYSZOWSKA M., KATSKA L., RYNSKA B., KANIA G., SMORAG Z. and PIENKOWSKI M. (2002) In vitro developmental competence of domestic cat embryos after somatic cloning; preliminary report. Theriogenology 58: 16151621.

SMORAG Z., GAJDA B., WIECZOREK B. and JURA J.(1989) Stage-dependent viability of vitrified rabbit embryos. Theriogenology 31: 1227-1231.

SMORAG Z., KATSKA L. and WIERZCHOS E. (1981) Some factors affecting viability of mouse and cattle embryos frozen to $-40^{\circ} \mathrm{C}$ before transfer to liquid nitrogen. Anim. Reprod. Sci. 4: 65-72.

SMORAGZ., WIERZBOWSKIS. and WIERZCHOS E. (1978) Results of transplanting 3, 6 and 7 days old frozen sheep embryos. Bull.L 'Acad.Pol.Sci, Vol XXVI, No 4: $273-275$. 


\section{Related, previously published Int. J. Dev. Biol. articles}

See our recent Special Issue Developmental Biology in Poland edited by Kloc, Maleszewski and Tarkowski at: http://www.ijdb.ehu.es/web/contents.php?vol=52\&issue=2-3

See our Special Issue Mammalian Reproduction \& Development in honor of Anne McLaren and edited by Brigid Hogan at: http://www.ijdb.ehu.es/web/contents.php?vol=45\&issue=3

The making of gametes in higher plants

Leonor C. Boavida, Jörg D. Becker and José A. Feijó

Int. J. Dev. Biol. (2005) 49: 595-614

P450 aromatase expression in the temperature-sensitive sexual differentiation of salamander (Hynobius retardatus) gonads

Natsuko Sakata, Yoichiro Tamori And Masami Wakahara

Int. J. Dev. Biol. (2005) 49: 417-425

A simple and efficient cryopreservation method for primate embryonic stem cells

Tsuyoshi Fujioka, Kentaro Yasuchika, Yukio Nakamura, Norio Nakatsuji and Hirofumi Suemori

Int. J. Dev. Biol. (2004) 48: 1149-1154

Yves Delage (1854-1920) as a forerunner of modern nuclear transfer experiments JEAN-CLAUDE BEETSCHEN and JEAN-LOUIS FISCHER

Int. J. Dev. Biol. (2004) 48: 607-612

mgm 1, the earliest sex-specific germline marker in Drosophila, reflects expression of the gene esg in male stem cells.

Adrian Streit, Luca Bernasconi, Pavel Sergeev, Alex Cruz and Monica SteinmannZwicky

Int. J. Dev. Biol. (2002) 46: 159-166

Musca domestica, a window on the evolution of sex-determining mechanisms in insects.

Andreas Dübendorfer, Monika Hediger, Géza Burghardt and Daniel Bopp

Int. J. Dev. Biol. (2002) 46: 75-79

The allocation and differentiation of mouse primordial germ cells.

T E Tsang, P L Khoo, R V Jamieson, S X Zhou, S L Ang, R Behringer and P P Tam Int. J. Dev. Biol. (2001) 45: 549-555

Differentiation of mouse primordial germ cells into female or male germ cells. N Nakatsuji and S Chuma

Int. J. Dev. Biol. (2001) 45: 541-548

Pattern regulation properties of a Hydra strain which produces additional heads along the body axis.

$S$ Zeretzke and S Berking

Int. J. Dev. Biol. (2001) 45: 431-439

The use of transgenic animals in biotechnology.

$\mathrm{K}$ M Ebert

Int. J. Dev. Biol. (1998) 42: 1003-108

In vitro production of cattle embryos: review and Belgian results.

P Mermillod, A Massip and F Dessy

Int. J. Dev. Biol. (1992) 36: 185-195

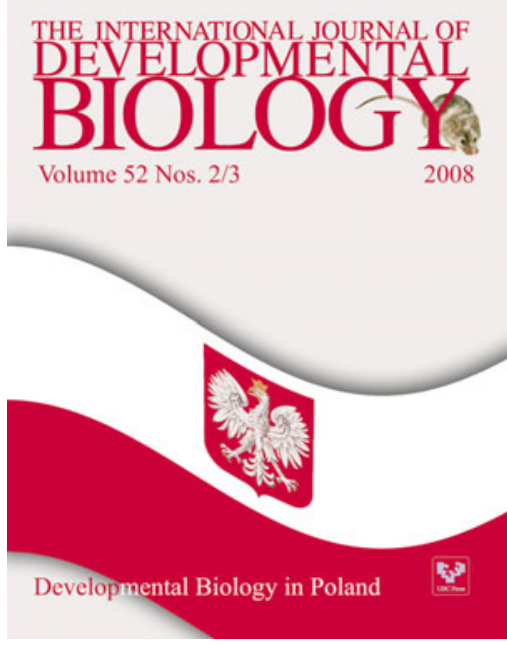

2006 ISI ${ }^{\star *}$ Impact Factor $=3.577^{\star \star}$

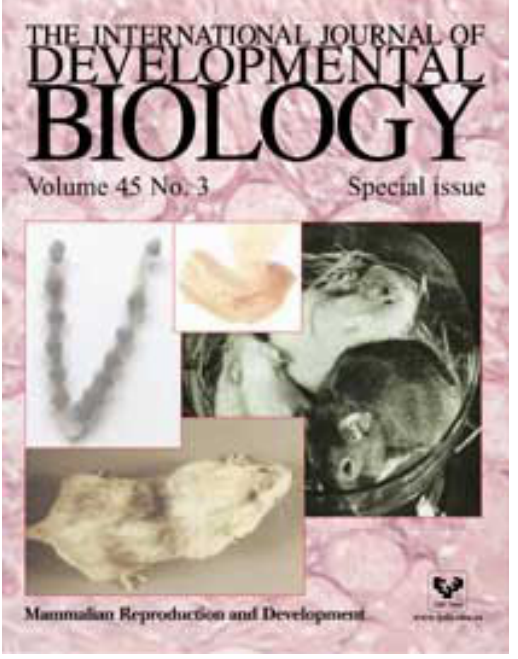

